\title{
A Case of Growth Hormone (GH) Deficient Adult with Tertiary Hypothyroidism who Showed Signs of Hyperthyroidism During GH Treatment
}

\author{
Mari Satoh ${ }^{1}$, Atsuko Yoshizawa', Toshiaki Tanaka1, Itsuro Hibi² \\ Endocrine Research Laboratory, National Children's Medical Research Center, (M.S.), (A.Y.), (T. \\ T.), Division of Endocrinology and Metabolism, National Children's Hospital, (I.H.), Tokyo, Japan.
}

\begin{abstract}
An adult patient with growth hormone deficiency (GHD) who showed signs of hyperthyroidism during growth hormone $(\mathrm{GH})$ treatment.

The patient was a 58-year-old male who contracted GHD, tertiary hypothyroidism, and hypogonadotropic hypogonadism and received levo-thyroxine (1-T4) (150 $\mu \mathrm{g} / \mathrm{day})$ and testosterone enantate replacement therapy (125mg/2weeks, i.m.). Three months after the GH treatment was started, he began to notice increased perspiration and decreased body weight. Just before he noticed these signs, his serum triiodothyronine (T3) was $2.6 \mathrm{ng} / \mathrm{ml}$ and T3/T4 ratio was 0.22 ; we therefore made the diagnosis of hyperthyroidism. After we reduced the 1-T4, these signs disappeared.

Although there are some reports about the effects of $\mathrm{GH}$ administration on thyroid function, there is no report of hyperthyroidism in a $\mathrm{GH}$ deficient patient during $\mathrm{GH}$ therapy. It is well known that peripheral conversion of $\mathrm{T} 4$ to $\mathrm{T} 3$ is increased by $\mathrm{GH}$. But it is possible that the appearance of hypothyroidism or hyperthyroidism during $\mathrm{GH}$ treatment is caused by differences in the basal thyroid function or in the dosage of replacement therapy.
\end{abstract}

Key words: Growth hormone deficient adult, growth hormone treatment, hyperthyroidism

\section{Introduction}

Growth hormone (GH) is essential for both height growth in children and metabolism of carbohydrate, fat, and protein [1]. GH may also relate to the process of senility,

Received: May 27, 1993

Accepted: September 29, 1993

Correspondece: Mari Satoh, Endocrine Research Laboratory, National Children's Medical Research Center, 3-35-31 Taishido, Setagaya-ku, Tokyo, 154 Japan because the 24-hour integrated concentration of $\mathrm{GH}$ decreases with age [2].

Recently genetic engineering has made the mass production of $\mathrm{GH}$ possible. $\mathrm{GH}$ administration to $\mathrm{GH}$-deficient adult patients has therefore been tried. $\mathrm{GH}$ substitution treatment has induced an increase in muscle strength [3] and a subjective improvement in general wellbeing [4].

We report here an adult patient with $\mathrm{GH}$ deficiency (GHD) who showed signs of hyperthyroidism during $\mathrm{GH}$ treatment. There are 


\section{SATOH et al.}

many reports on the effect of $\mathrm{GH}$ on thyroid function [5-14]. But no report describing hypothyroidism $[9,10]$, or hyperthyroidism during $\mathrm{GH}$ treatment has been published.

\section{Case Report}

The patient was a 58 -year-old male born by breech delivery. His birth weight was $820 \mathrm{~g}$ but his gestational age was unknown. Severe asphyxia and jaundice had been observed. At the age of 16 years, he had received a cow hypophysis transplant. At 45 years, he was referred to the division of endocrinology and metabolism, National Children's Hospital. At that time he was $140.8 \mathrm{~cm}$ tall and his body weight was $32.8 \mathrm{~kg}$. Pubertal development was at Tanner Scale stage 1 . His bone age was 15 years and 6 months (Greulich and Pyle). Endocrinological data were as follows. Peak GH values after stimulation with glucagonpropranolol and arginine were $0.7 \mathrm{ng} / \mathrm{ml}$ and $0.3 \mathrm{ng} / \mathrm{ml}$, respectively. Serum triiodothyronine (T3) was $0.7 \mathrm{ng} / \mathrm{ml}$, and serum thyroxine (T4) was $3.9 \mu \mathrm{g} / \mathrm{dl}$. Basal thyrotropin (TSH) was $15 \mu \mathrm{U} / \mathrm{ml}$ and peak TSH after thyrotropin-releasing hormone (TRH) provocation test was $110 \mu \mathrm{U} / \mathrm{ml}$ at 120 minutes. Basal luteinizing hormone (LH) and folliclestimulating hormone (FSH) values were 4 . $7 \mathrm{mIU} / \mathrm{ml}$ and $3.1 \mathrm{mIU} / \mathrm{ml}$, respectively. Peak $\mathrm{LH}$ and $\mathrm{FSH}$ values after $\mathrm{LH}$-releasing hormone (LHRH) provocation test were $17.5 \mathrm{mIU} /$ $\mathrm{ml}$ and $4.0 \mathrm{mIU} / \mathrm{ml}$ respectively. Basal testosterone was $4.4 \mathrm{ng} / \mathrm{dl}$, and peak testosterone after human chorionic gonadotropin (HCG) test was $26.0 \mathrm{ng} / \mathrm{dl}$. The patient was diagnosed as GHD, tertiary hypothyroidism and hypogonadotropic hypogonadism. He received $1-\mathrm{T} 4(150 \mu \mathrm{g} / \mathrm{day})$ and testosterone enantate $(125 \mathrm{mg} / 2$ weeks, i.m.) replacement therapy. His final height reached $146.7 \mathrm{~cm}$.

At the age of 58 years, $\mathrm{GH}$ treatment was started with recombinant human $\mathrm{GH}(4 \mathrm{U} /$ day, $0.5 \mathrm{U} / \mathrm{kg} /$ week, s.c.). Figure 1 shows the process during this treatment. At 2 months after $\mathrm{GH}$ treatment, he had generalized edema

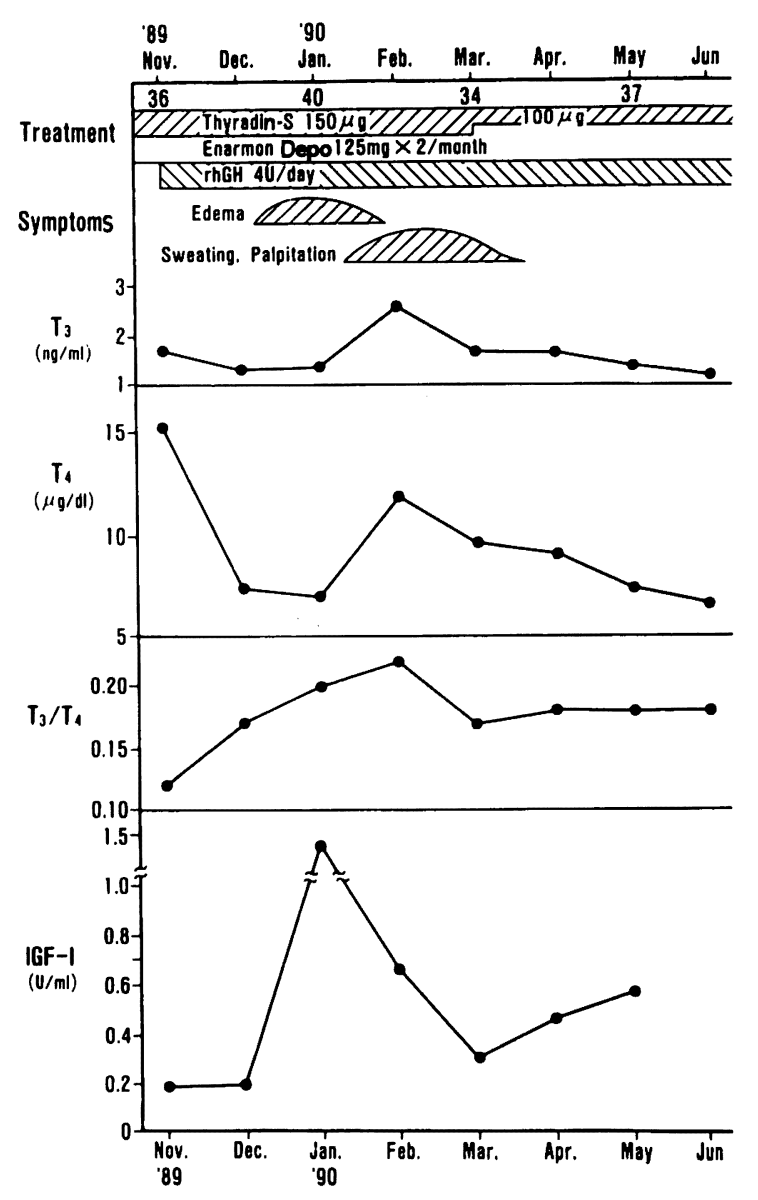

Fig. 1 Process during GH treatment.

and his body weight had increased by $4 \mathrm{~kg}$. These signs improved without cessation of GH or other treatment. One month later perspiration increased, and body weight decreased by $6 \mathrm{~kg}$. Just before these signs, serum T3 was 2 . $6 \mathrm{ng} / \mathrm{ml}$ and the T3/T4 ratio was 0.22 , so that a diagnosis of hyperthyroidism was made. At that time, TSH receptor antibody was negative. After we reduced the dose of 1-T4 from 150 to $100 \mu \mathrm{g} / \mathrm{day}$, these signs disappeared. Although the patient continued GH treatment for 1 year and 4 months, no other adverse effects have been observed.

\section{Discussion}

Generalized edema due to fluid retention by $\mathrm{GH}$ is known to be one of the side-effects of 
GH treatment in adult GHD. The mechanism of water retention by $\mathrm{GH}$ has been considered to be augmented sodium pump activity [15]. Increased extracellular water during GH substitution treatment has been demonstrated in hypopituitary patients [16]. In patients with acromegaly, increased total body water, plasma volume, extracellular fluid and exchangeable sodium returned to normal after successful treatment of the $\mathrm{GH}$ hypersecretion [17-19].

When this patient first visited our hospital, serum T4 and T3 values were low, and basal and peak TSH values were high. Illig et al. [20] reported that some GH-deficient patients with signs of hypothyroidism showed elevated basal TSH levels and an exaggerated $\mathrm{TSH}$ response to TRH; they excluded primary hypothyroidism on the basis of an increase in plasma T4 after intravenous stimulation with TRH. Hibi reported that 8 of 80 patients with idiopathic complete $\mathrm{GH}$ deficiency showed exaggerated TSH responses to TRH [21]. The reason why some tertiary hypothyroid patients show high TSH levels is unclear. Patients with hypothalamic disorders may secrete a biologically less active form of TSH [22]. Sato et al. [23] reported that the set point of TSH in feedback inhibition by thyroxine was low in idiopathic hypopituitarism with TRH deficiency. Beck-Peccoz et al. [24] reported that in certain cases of hypothalamic hypopituitarism, secreted TSH lacked biologic activity because of impaired binding to its receptor, and that TRH treatment might correct this defect.

There are many reports on the effects of $\mathrm{GH}$ on thyroid function. Oliner and Ballantine [5] administered human $\mathrm{GH}(\mathrm{hGH})$ to healthy adult subjects for a short time and found no significant effects on thyroid function, apart from a small decline in the binding capacity of T4-binding globulin. The decline in T4binding globulin was paralleled by a decline in serum total protein and albumin, and therefore might be caused by fluid retention following $\mathrm{GH}$ administration. Lippe et al. [9] reported decreased $\mathrm{T} 4$ concentration during $\mathrm{hGH}$ treatment in GH-deficient children who showed poor growth responses and whose growth was improved after thyroid hormone administration. Because TSH response to TRH was absent or markedly blunted during long-term hGH therapy, they suggested that exogeneous $\mathrm{GH}$ increased somatostatin secretion and resulted in an inhibition of the TSH response to $\mathrm{TRH}$. It has been reported that serum $\mathrm{T} 3$ and the $\mathrm{T} 3 / \mathrm{T} 4$ ratio are elevated during $\mathrm{GH}$ administration in GH-deficient children $[10,11,14]$, normal men [12], and GH-deficient adults [13]. J $\phi$ rgensen et al. [13] pointed out that many catabolic conditions were accompanied by an impaired peripheral conversion of $\mathrm{T} 4$ to $\mathrm{T} 3[25,26]$, and that in most of these conditions, serum GH was substantially elevated, whereas IGF-1 levels were low $[27,28]$. They therefore considered that the increased conversion of T4 to T3 during $\mathrm{GH}$ administration was mediated through an increase in IGF-1.

We observed increases in serum T3 (2. $6 \mathrm{ng} / \mathrm{ml})$ and the $\mathrm{T} 3 / \mathrm{T} 4$ ratio $(0.22)$ with no change of $\mathrm{T} 4(11.8 \mu \mathrm{g} / \mathrm{dl})$ in the present case. Serum T3 $(2.6 \mathrm{ng} / \mathrm{ml})$ was high in this patient, given that serum T3 concentrations progressively decrease with age [29]. From the clinical symptoms such as palpitation and increased sweating, hyperthyroidism was diagnosed. Without any TRH-TSH-thyroid axis disorder, increased T3 would have inhibited TSH secretion, T4 secretion would have decreased, and conversion of $\mathrm{T} 4$ to $\mathrm{T} 3$ would also decrease. However, since the patient was receiving $\mathrm{T} 4$ replacement therapy, the increased conversion of $\mathrm{T} 4$ to $\mathrm{T} 3$ by $\mathrm{GH}$ had produced hyperthyroidism. It might be possible that the dosage of 1-T4 was slightly high for him and that the slightly high T4 level at the start of GH treatment contributed to the development of hyperthyroidism by increased conversion of T4 to T3, although he had not shown any signs of hyperthyroidism before $\mathrm{GH}$ treatment. It could therefore be possible that the appearance of hypothyroidism or hyperthyroidism during $\mathrm{GH}$ treatment depends on differences in basal thyroid func- 
tion or on the dose of replacement therapy.

\section{References}

1. Davidson MB. Effect of growth hormone on carbohydrate and lipid metabolism. Endocr Rev. 1987; 8: 115-31.

2. Zadik Z, Chalew SA, McCarter RJ, Meistus $\mathrm{M}$, Kowarski AA. The influence of age on the 24-hour integrated concentration of growth hormone in normal individuals. $J$ Clin Endocrinol Metab. 1985; 60: 513-6.

3. J $\phi$ rgensen JOL, Pedersen SA, Thuesen L,

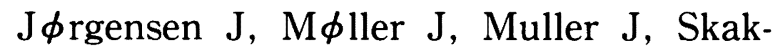
kebaek NE, Christiansen JS. Long-term growth hormone treatment in growth hormone deficient adults. Acta Endocrinol (Copenh). 1991; 125: 449-53.

4. Degerblad M, Almkvist O, Grunditz R, Hall K, Kaijser L, Knutsson E, Ringertz H, Thoren M. Physical and psychological capabilities during substitution therapy with recombinant growth hormone in adults with growth hormone deficiency. Acta Endocrinol (Copenh). 1990; 123: 18593.

5. Oliner L, Ballantine JJ. Effect of human growth hormone on thyroid secretion, radiothyroxine turnover and transport in man. J Clin Endocrinol Metab. 1968; 28: 603-7.

6. Root AW, Bongiovanni AM, Eberlein WR. Inhibition of thyroidal radioiodine uptake by human growth hormone. J Pediatr. 1970; 76: 422-9.

7. Root AW, Snyder PJ, Rezvani I, DiGeorge AM, Utiger RD. Inhibition of thyrotropinreleasing hormone-mediated secretion of thyrotropin by human growth hormone. J Clin Endocrinol Metab. 1973; 36: 103-7.

8. Porter BA, Refetoff S, Rosenfield RL, De Groot LJ, Fang VS, Stark V. Abnormal thyroxine metabolism in hyposomatotropic dwarfism and inhibition of responsiveness to TRH during GH therapy. Pediatrics. 1973; 51: 668-74.

9. Lippe BM, Van Herle AJ, LaFranchi SH,
Uller RP, Lavin N, Kaplan SA. Reversible hypothyroidism in growth hormonedeficient children treated with human growth hormone. J Clin Endocrinol Metab. 1975; 40: 612-8.

10. Sato T, Suzuki Y, Taketani T, Ishiguro K, Masuyama T, Takata I, Sano M, Kawashima H, Koizumi S, Nakajima H. Enhanced peripheral conversion of thyroxine to triiodothyronine during $\mathrm{hGH}$ therapy in GH-deficient children. J Clin Endocrinol Metab. 1977; 45: 324-9.

11. Rezvani I, DiGeorge AM, Dowshen SA, Bourdony CJ. Action of human growth hormone $(\mathrm{hGH})$ on extrathyroidal conversion of thyroxine (T4) to triiodothyronine (T3) in chidren with hypothyroidism. Pediatr Res. 1981; 15: 6-9.

12. Grunfeld C, Shermann BM, Cavalieri RR. The acute effects of human growth hormone administration on thyroid function in normal men. J Clin Endocrinol Metab. 1988; 67: 1111-4.

13. J $\phi$ rgensen JOL, Pedersen SA, Laupberg P, Weeke J, Skakkebaek NE, Christiansen JS. Effects of growth hormone therapy on thyroid function of growth hormone-deficient adults with and without concomitant thyroxine-substituted central hypothyroidism. J Clin Endocrinol Metab. 1989; 69: 1127-32.

14. Pirazzoli P, Cacciari E, Mandini M, Sganga T, Capelli M, Cicognani A, Gualandi S. Growth and thyroid function in children treated with growth hormone. J Pediatr. 1992; 121: 210-3.

15. Ng LL, Evans DJ. Leukocyte sodium transport in acromegaly. Clin Endocrinol (Oxf). 1987; 26: 471-80.

16. Novak LP, Hayles AB, Cloutier MD. Effect of $\mathrm{hGH}$ on body composition of hypopituitary dwarfs. Mayo Clin Proc 1972; 47: 241-6.

17. Strauch G, Lego A, Therain F, Briacaire H. Reversible plasma red blood cell volume increases in acromegaly, Acta Endocrinol (Copenh). 1977; 85: 465-78.

18. McLellan A Beastall GH, Connel JMC, 
Teasdale GM, Davies DL. Body composition and serum growth hormone in treated acromegaly. J Endocrinol. 1987; (Suppl 112): 185.

19. Bengtsson B-A, Brummer R-JM, Eden S, Bosaeus I. Body composition in acromegaly. Clin Endocrinol (Oxf). 1987; 26: $471-80$.

20. Illig R, Krawczynska $H$, Torresani $T$, Prader A. Elevated plasma TSH and hypothyroidism in children with hypothalamic hypopituitarism. J Clin Endocrinol Metab. 1975; 41: 722-8.

21. Hibi I. Pituitary dwarfism In Shin shouni igaku taikei 16B, p.293, Nakayama shoten, Tokyo, 1985. (In Japanese)

22. Martin JB, Boshans R, Reichlin S. Feedback regulation of TSH secretion in rats with hypothalamic lesions. Endocrinology. 1970; 87: 1032.

23. Sato T, Ishiguro K, Suzuki Y, Taketani T, Izumisawa A, Masuyama T, Nagaoki T, Koizumi S, Nakajima H. Low setting feedback regulation of TSH secretion by thyroxine in pituitary dwarfism with TSHreleasing hormone deficiency. J Clin Endocrinol Metab. 1976; 42: 385-90.
24. Beck-Peccoz P, Amr S, Menezes-Ferreira MM, Faglia G, Weintraub BD. Decreased receptor binding of biologically inactive thyrotropin in central hypothyroidism. N Engl J Med. 1985; 312: 1085-90.

25. Cavalieri RR, Rapoport B, Impaired peripheral conversion of thyroxine to triiodothyronine. Annu Rev Med. 1977; 28: 57-65.

26. Utiger RD. Decreased extrathyroidal triiodothyronine production in nonthy. roidal illness: benefit or harm. Am J Med. 1980; 69: 807-10.

27. Clemmons DR, Klibanski A, Underwood LE. Reduction of plasma immunoreactive somatomedin-C during fasting in humans. J Clin Endocrinol Metab. 1981; 53: 1247-50.

28. Ho KY, Veldhuis JD, Johnson ML, Furlanetto R, Evans W, Alberti KGMM, Thorner MO. Fasting enhances growth hormone secretion in man. J Clin Endocrinol Metab. 1988; 81: 969-75.

29. Rubenstein HA, Butler VP Jr, Werner SC. Progressive decrease in serum triiodothyronine concentrations with human aging: radioimmunoassay following extraction of serum. J Clin Endocrinol Metab. 1973; 37: 247-53. 